\title{
Effect of Germination Media and Saline Water on Germination of Chia (Salvia hispanica L.) Seeds
}

\author{
Moghith, W. M. A. ${ }^{2}$; Youssef, A. S. M. ${ }^{1}$; Abd El-Wahab, M. A. ${ }^{\text {; }}$ Mohamed, Y. F. Y. ${ }^{1}$ and Abou El- \\ Ghait, Eman M. ${ }^{1}$ \\ 1- Horticulture Department, Faculty of Agriculture, Benha University, Egypt. \\ 2- Medicinal and Aromatic Plants Department, Desert Research Center, Cairo, Egypt. \\ Corresponding author: walidmoghith@gmail.com
}

\begin{abstract}
This study was conducted at the Lab of Desert Research Center, during the two successive seasons of 2016/2017 and 2017/2018. The aim of this study was to investigate the tolerance of Salvia hispanica L. seeds germinated in filter paper or grown in sandy soil to water salinity irrigation. The seeds were irrigated (till 100\% of field capacity) every two days using tap water (control, $0.42 \mathrm{dS} \mathrm{m}^{-1}$ ) or saline water containing of $\mathrm{NaCl}$ at a concentration of $2.34,3.13,3.91$ and $4.69 \mathrm{dS} \mathrm{m}^{-1}$. Saline water was used from the beginning of seed sowing till full germination (from 10-17 days). The recorded results indicated that filter paper medium is more effective in reducing the unfavorable effects of salinity on the most of the studied germination parameters than sand. Raising the salt concentration in irrigation water up to $4.69 \mathrm{dS} \mathrm{m}^{-1}$ decreased the most of germination parameters (germination percentage, germination index and mean germination rate of chia seeds). The highest values of above mentioned parameters were gained by the combination of $0.42 \mathrm{dS} \mathrm{m}^{-1}$ concentration (control), especially those germinated on filter paper, followed descendingly by $2.34 \mathrm{dS} \mathrm{m}^{-1}$ concentration with the filter paper growing medium in both seasons. Also, the highest mean of daily germination and germination value were recorded by grown chia seed in filter paper and irrigated with saline water at $2.34 \mathrm{dS} \mathrm{m}^{-1}$ in $1^{\text {st }}$ and $2^{\text {nd }}$ seasons, while seeds grown in the same above mentioned medium and irrigated with saline water at $2.34 \mathrm{dS} \mathrm{m}^{-1} \mathrm{scored}$ the highest peak value for germination in both seasons. Furthermore the highest values of coefficient of variation of germination time were gained by the combination treatments of the highest salinity concentration $4.69 \mathrm{dS} \mathrm{m}^{-1}$ with the filter paper growing medium in both seasons. On the other hand the combination of growing sand medium and irrigation with saline water at $3.91 \mathrm{dS} \mathrm{m} \mathrm{m}^{-1}$ concentration showed to be the most effective one for producing the highest mean germination time, time to $50 \%$ germination and time to $90 \%$ germination of chia seeds in both seasons. Conclusively, using filter paper as the germination medium produced the best germination parameters at the lowest salinity level $0.42 \mathrm{dS} \mathrm{m}{ }^{-1}$. On the other hand, the filter paper growing medium reduced, to some extent, the negative effect of salinity on chia seed germination parameters.
\end{abstract}

Keywords: Salvia hispanica, Chia, Germination, Saline water, Salinity, Germination media.

\section{Introduction}

Chia (Salvia hispanica L.) is an annual plant belonging to family Labiate native to Guatemala and Mexico (Ixtaina, et al., 2008). In pre-Columbian times, chia seeds were one of the basic foods of Central American Civilizations (Ayerza and Coates, 2005). The cultivation of chia is gaining popularity in Africa because it is considered as a good nutritional and healthy food for two strains of hens (Ayerza and Coates, 2000).

The seed of chia contains from $25 \%$ to $40 \%$ fixed oil with $60 \%$ of its comprising $\alpha$-linolenic acid (omega-3) and $20 \%$ of linoleic acid (omega-6). Chia can grow up to $100 \mathrm{~cm}$ tall and has opposite arranged leaves. Chia flowers are small flower (3-4 mm) with small corollas and fused flower parts that contribute to a high self-pollination rate. The seed color varies from black, gray, and black spotted to white and the shape is oval with size ranging from 1 to $2 \mathrm{~mm}$ (Ali, et al., 2012; Bresson, et al., 2009; Peiretti and Meineri, 2008; Reyes-Caudillo, et al., 2008; Cahill and Provance, 2002)

Chia seed is composed of protein (15-25\%), fats (30-33\%), carbohydrates (26-41\%), high dietary fiber
(18-30\%), ash (4-5\%), minerals, vitamins, and dry matter (90-93\%). It also contains a high amount of antioxidants (Ixtaina, et al., 2008). Chia seed is free of gluten (Bueno, et al., 2010). Clearly, any reliable source of omega-3 fatty acid that can be found which is safe for consumption would be attractive (Ayerza and Coates, 2005). Chia can grow in arid environments, it has been highly recommended as an alternative crop for the field crop industry (Peiretti and Gai, 2009).

The lack of standardized methods of analyses, as Salvia hispanica is a species not yet covered by the Rules for Testing Seeds (Paiva, et al., 2016 and I. S. T. A., 2013). Germination of seed in a laboratory test is essential structures, which indicates whether or not it is able to develop further into a satisfactory plant under favorable conditions in soil (I. S. T. A., 2007)

There is poor information on the relationship between growing media and seed germination and growth of Salvia hispanica L. one of the most important criteria for successful germination is a reliable germination medium. The influence of the medium is felt even before the plant sprout (Ndor, et al., 2012). Good and suitable nursery potting media 
influence good and quality seedling production (Agbo and Omaliko, 2006).

Kumar and Sharma, (2012) studied the germination of three plants Stevia rebaudiana, Tagets minuta and Salvia sclarea, the results of Salvia sclarea show that filter paper gave the highest germination percentage compared to sand, while the other two plants were in the opposite direction. Filter paper enhanced germination percentage, germination rate, germination index and mean daily germination compared to sand (Trivedia and Joshi, 2014).

Environmental stresses such as salinity affect nearly every aspect of the physiology and biochemistry of plants and significantly reduce the yield. At present, about $20 \%$ of the world's cultivated land and approximately half of all irrigated land are affected by salinity (Heidari, 2012).

Salinity is one of the most significant stress factors affected crop productivity (Munnas, 1993). Although higher salinity decreases germination, the detrimental effect of salinity is generally less severe at optimum germination temperature (Al-Khateeb, 2006; Gorai and Neffati, 2007 and Tlig, et al., 2008). Salt stress is becoming a significant global factor as affected nearly $20 \%$ of global irrigated land because it limits production in terms of agriculture in the worldwide (Flowers and Yeo, 1995). Salinity affects different physiological life stages of medicinal plants and of the most important stage life of the plant are germination period under salinity conditions (Sosa, et al., 2005).

The aim of this study was to investigate the effects of five salinity levels $\left(0.42 \mathrm{dS} \mathrm{m}^{-1}\right.$ as control, 2.34, 3.13, 3.91 and $4.69 \mathrm{dS} \mathrm{m} \mathrm{m}^{-1}$ ) using filter paper and sand as germination media on chia seed germination.

\section{Material and methods}

This investigation was carried out at the Experimental Laboratory of the Desert Research Center (geographical latitude $30^{\circ} 07^{\prime} 16^{\prime \prime} \mathrm{N} 31^{\circ} 18^{\prime}$ 55" E), El Matareya, Cairo, Egypt, during the two successive seasons of 2016/2017 and 2017/2018. The objective of this work was to study the effect of two growing media (filter paper and sand) and different levels of water salinity irrigation on germination characteristics of Salvia hispanica L. seeds produced under Egyptian environmental conditions. Seeds of Salvia hispanica $\mathrm{L}$. were collected from plants grown on a private farm in Toukh - El Qlubia Governorate, Egypt in February in both seasons 2016/2017 and $2017 / 2018$. The weight of 1000 seeds is ranged 1.04 - $1.56 \mathrm{~g}$. The seed color varies from black, gray and black spotted to white and the shape is oval with size ranging from 1 to $2 \mathrm{~mm}$, the seeds (black after manually exclude white) were sown on $9^{\text {th }}$ November 2017 and 2018 (in the first and second seasons, respectively), in petri dishes $(12 \mathrm{~cm})$ on filter paper Whatman No. 1 and in cardboard pots $10 \mathrm{~cm}$ filled with washed sand (three times with sterilized water).

The layout of the experiment was factorial experiments in a complete randomized block design with 10 treatments represented the combinations between the germination media (filter paper and sand) and the irrigation water salinity treatments $\left(0.42 \mathrm{dS} \mathrm{m}^{-1}\right.$ as control, 2.34, 3.13, 3.91 and $4.69 \mathrm{dS}$ $\mathrm{m}^{-1}$ ) (2 germination media $\mathrm{x} 5$ salinity treatments), with 3 (replicates) each replicate contain 50 seeds. Then, petri dishes and pots were placed in room temperature $\left(25-30^{\circ} \mathrm{C}\right)$ and lighting was $8 \mathrm{~h}$ of light alternating by $16 \mathrm{~h}$ of dark. 40 fluorescent lamps were used as a source of white light. $10 \mathrm{ml}$ of water was supplied every two days to avoid drought stress, 10-17 days after treatments the following data were recorded and calculated:

The analysis of the tap water and the high salinity water $\left(4.69 \mathrm{dS} \mathrm{m}^{-1}\right)$ are presented in Tables (1 and 2).

\section{Data recorded:}

- Germination percentage [G. P. (\%)].

- Mean germination Time [M. G. T. (day)].

- Mean germination Rate [M. G. R. $\left(\right.$ day $\left.\left.^{-1}\right)\right]$.

- Germination index [G. I. (seed day-1)].

- Coefficient of variation of germination time $\left[\left(\mathrm{C} . \mathrm{V}_{\mathrm{t}}(\%)\right]\right.$.

- Mean daily germination [M. D. G. $\left(\right.$ day $\left.\left.^{-1}\right)\right]$.

- Peak value for germination [P.V. $\left.\left(\mathrm{day}^{-1}\right)\right]$.

- Germination value [G. V. $\left(\%^{2}\right.$ day $\left.\left.^{-2}\right)\right]$.

- Time to $50 \%$ germination $\left[\mathrm{T}_{50}\right.$ (day)].

- $\quad$ Time to $90 \%$ germination [ $\mathrm{T}_{90}$ (day)].

Table 1. Water analysis of the tap water (Control)

\begin{tabular}{|c|c|c|c|c|c|c|c|c|c|}
\hline \multirow{2}{*}{$\mathbf{P h}$} & \multirow{2}{*}{$\begin{array}{c}\text { E.C. } \\
\left(\mathrm{dS} \mathbf{m}^{-1}\right)\end{array}$} & \multicolumn{4}{|c|}{ Soluble cations $\left(\mathbf{m m o l c} \mathbf{L}^{-1}\right)$} & \multicolumn{4}{|c|}{ Soluble anions $\left(\operatorname{mmolc} \mathbf{L}^{-1}\right)$} \\
\hline & & $\mathbf{C a}^{++}$ & $\mathbf{M g}^{++}$ & $\mathrm{Na}^{+}$ & $\mathbf{K}^{+}$ & $\mathrm{Co3}^{--}$ & $\mathrm{HCo3}^{-}$ & So4-- & $\mathrm{Cl}^{-}$ \\
\hline 7.1 & 0.42 & 1.43 & 1.32 & 1.47 & 0.20 & 0.00 & 2.49 & 0.79 & 1.14 \\
\hline
\end{tabular}

Analyzed in the Desert Research Center laboratories according to Rainwater and Thatcher, (1960).

Table 2. Water analysis of the high salinity water $\left(4.69 \mathrm{dS} \mathrm{m}^{-1}\right)$

\begin{tabular}{|c|c|c|c|c|c|c|c|c|c|}
\hline \multirow{2}{*}{ pH } & \multirow{2}{*}{$\begin{array}{c}\text { E.C. } \\
\left(\mathbf{d S} \mathbf{m}^{-1}\right)\end{array}$} & \multicolumn{4}{|c|}{ Soluble cations (mmolc $\left.\mathbf{L}^{-1}\right)$} & \multicolumn{4}{|c|}{ Soluble anions $\left(\right.$ mmolc $\left.\mathrm{L}^{-1}\right)$} \\
\hline & & $\mathrm{Ca}^{++}$ & $\mathrm{Mg}^{++}$ & $\mathrm{Na}^{+}$ & $\mathbf{K}^{+}$ & $\mathrm{Co3}^{--}$ & $\mathrm{HCO}^{-}$ & So4-- & $\mathrm{Cl}^{-}$ \\
\hline 6.8 & 4.69 & 3.99 & 2.02 & 39.83 & 0.20 & 0.00 & 2.60 & 5.70 & 37.74 \\
\hline
\end{tabular}

Analyzed in the Desert Research Center laboratories according to Rainwater and Thatcher, (1960). 
Germination associate parameters were calculated by using the following formulas:

- Germination percentage (G. P.)

Was calculated using the following formula given by (I. S. T. A., 1999)

Germination $\%=\frac{\text { No. of germinated seeds }}{\text { Total No. of seeds }} \times 100$

- Mean germination time (M. G. T.)

Mean germination time was calculated by the formula given by (Ellis and Roberts, 1981).

M. G. $\mathrm{T}=\frac{\mathrm{n} 1 \mathrm{xd} 1+\mathrm{n} 2 \mathrm{xd} 2+\mathrm{n} 3 \mathrm{xd} 3+\cdots}{\text { Total number of days }}$

Where: $\mathrm{n}=$ number of germinated seeds and $\mathrm{d}=$ number of days.

- Mean daily germination (M. D. G.)

Mean daily germination can be calculated by the following formula given by (Czabator, 1962)

$$
\text { M. D. } G=\frac{\text { Total number of germinated seeds }}{\text { Total number of days }}
$$

- Peak value (P. V.)

Peak value was calculated by the following formula given by (Czabator, 1962)

$$
\mathrm{P} . \mathrm{V}=\frac{\text { The highest seed germinated }}{\text { Number of days }}
$$

- Germination value (G. V.)

Germination value was calculated by the following formula given by (Czabator, 1962)

$$
\text { G. V. = PV X MDG }
$$

- Germination index (G. I.)

Germination index was calculated as described in the association of official seed analysis (A. O. S. A., 1983) by the following formula: G. I. =

$$
\left(\frac{\text { No of germination seeds }}{\text { Days of first count }}+----+\frac{\text { No of germination seeds }}{\text { Days of last count }}\right)
$$

- Coefficient of variation of germination time $\left(\mathbf{C} . V_{t}\right)$.

Coefficient of variation of the germination time is calculated by the following formula given by by (Ranal and Santana, 2006)

$$
\text { C. } \mathrm{V}_{\mathrm{t}}=\frac{S t}{\bar{t}} \times 100
$$

Where: $s_{t}:$ standard deviation of the germination time and $\bar{t}$ : mean germination time.

\section{- $\quad$ Time to $50 \%$ germination $\left(\mathbf{T}_{50}\right)$}

The time to reach $50 \%$ germination $\left(\mathrm{T}_{50}\right)$ was calculated according to the following formula of Coolbear, et al., (1984) modified by Farooq, et al., (2005):

$$
\mathrm{T}_{50}=\mathrm{t}_{\mathrm{i}}+\left[\left(\mathrm{N} / 2-\mathrm{n}_{\mathrm{i}}\right)\left(\mathrm{t}_{\mathrm{i}}-\mathrm{t}_{\mathrm{j}}\right)\right] /\left[\mathrm{n}_{\mathrm{i}}-\mathrm{n}_{\mathrm{j}}\right] .
$$

Where: $\mathrm{N}$ is the final number of emergence and $n_{i}, n_{j}$ cumulative number of seeds germinated by adjacent counts at times $t_{i}$ and $t_{j}$, respectively when $n_{i}<N / 2$ $<\mathrm{n}_{\mathrm{j}}$.

\section{- $\quad$ Time to $90 \%$ germination $\left(\mathrm{T}_{90}\right)$}

The time to reach $90 \%$ germination $\left(\mathrm{T}_{90}\right)$ was calculated according to Carbonell, et al., (2008):

$\mathrm{T}_{90}=\mathrm{t}_{\mathrm{i}}+\left[\left(90 \mathrm{~N} / 100-\mathrm{n}_{\mathrm{i}}\right)\left(\mathrm{t}_{\mathrm{i}}-\mathrm{t}_{\mathrm{j}}\right)\right] /\left[\mathrm{n}_{\mathrm{i}}-\mathrm{n}_{\mathrm{j}}\right]$.

Where: $\mathrm{N}$ is the final number of seeds germinated, and $\mathrm{ni}$ and $\mathrm{nj}$ are the total number of seeds germinated in adjacent counts in time ti and $\mathrm{tj}$, respectively, when $n_{i}<90 \mathrm{n} / 100<n_{j}$.

\section{Statistical analysis}

All data obtained in both seasons of study were subjected to analysis of variance as factorial experiments in a complete randomized block design. The results were statistically analyzed using MSTAT-C Statistical Software according to (Sendecor and Cochran, 1989). The differences between the mean values of various treatments were compared by Duncan's multiple range test (Duncan, 1955).

\section{Results}

- Effect of germination media, saline water and their interaction treatments on:

\section{1- Germination percentage $(\%)$}

Data in Table (3) showed that, using filter paper as a germination media showed to be the most effective one for producing the highest germination percentage as it reached $93.20 \%$ and $93.60 \%$ of chia (Salvia hispanica L.) seeds in the first and the second seasons, respectively.

As for the effect of salinity on germination percentage data in the same Table illustrated that, all tested concentrations of salinity decreased germination percentage of chia seeds in both seasons. Irrespective control, the highest germination percentage was detected by $2.34 \mathrm{dS} \mathrm{m}^{-1}$ treated seeds, followed in descending order by $3.13 \mathrm{dS} \mathrm{m}^{-1}$ treated chia seeds without significant differences between them in the two seasons.

Concerning the interaction effect between germination media and salinity, it was found that all resulted combination between germination media and salinity decreased the germination percentages of chia seeds in $1^{\text {st }}$ and $2^{\text {nd }}$ seasons. The highest germination percentage was gained by the combination of $0.42 \mathrm{dS} \mathrm{m}^{-1}$ concentration (control), especially those germinated on filter paper of both seasons.

On the contrary, the lowest germination percentage was scored by the combination of high salinity concentration, particularly those germinated on sand media on the two seasons. The remained treatments occupied an intermediate position between the above mentioned treatments.

\section{2- Mean germination time (M. G. T)}

Data in Table (3) illustrated that, sand medium recorded the highest values of mean germination time of chia seeds as compared to the other medium (filter paper) in the two seasons. On the other hand, all the concentrations of salinity increased mean germination time of chia seed, especially with $3.91 \mathrm{dS} \mathrm{m} \mathrm{m}^{-1}$, followed descendingly 
by $4.69 \mathrm{dS} \mathrm{m} \mathrm{m}^{-1}$ concentration with non-significant between them in the two seasons.

On the reverse the lowest values of this parameter were recorded by control $0.42 \mathrm{dS} \mathrm{m}^{-1}$ of both seasons. Moreover, data in Table (3) indicate that all the interactions between germination media and salinity increased mean germination time of chia seeds, especially using sand medium and $3.91 \mathrm{dS} \mathrm{m}^{-1}$ concentration followed in descendingly by the combination treatment between sand medium with $4.69 \mathrm{dS} \mathrm{m}^{-1}$ in the two seasons.

The lowest values of this parameter were gained by all the combination treatments of filter paper as a germination medium and all tested concentrations of salinity particularly the low concentration of $0.42 \mathrm{dS}$ $\mathrm{m}^{-1}$ (control) and $2.34 \mathrm{dS} \mathrm{m} \mathrm{m}^{-1}$ in the first and the second seasons.

Table 3. Effect of germination media, saline water and their interaction treatments on germination percentage (\%) and mean germination time (day) of chia (Salvia hispanica L.) seeds

\begin{tabular}{|c|c|c|c|c|c|c|}
\hline \multirow{3}{*}{ Salinity } & \multicolumn{3}{|c|}{ G. P. $(\%)$} & \multicolumn{3}{|c|}{ M. G. T (day) } \\
\hline & \multicolumn{2}{|c|}{ Media } & \multirow{2}{*}{ Mean } & \multicolumn{2}{|c|}{ Media } & \multirow{2}{*}{ Mean } \\
\hline & F.P. & Sand & & F. P. & Sand & \\
\hline \multicolumn{7}{|c|}{$1^{\text {st }}$ season } \\
\hline $0.42 \mathrm{dS} \mathrm{m}^{-1}$ & $94.00 \mathrm{a}$ & $84.67 \mathrm{abc}$ & $89.33 a$ & $2.63 \mathrm{~d}$ & $6.88 \mathrm{c}$ & $4.62 b$ \\
\hline $2.34 \mathrm{dS} \mathrm{m}^{-1}$ & $93.33 \mathrm{ab}$ & 81.33abc & $87.33 \mathrm{a}$ & $2.37 \mathrm{~d}$ & $8.82 \mathrm{ab}$ & $5.60 \mathrm{a}$ \\
\hline $3.13 \mathrm{dS} \mathrm{m}^{-1}$ & $93.33 \mathrm{ab}$ & $78.67 \mathrm{bc}$ & $86.00 \mathrm{a}$ & $2.61 \mathrm{~d}$ & $8.21 \mathrm{~b}$ & $5.41 \mathrm{ab}$ \\
\hline $3.91 \mathrm{dS} \mathrm{m}^{-1}$ & $93.33 \mathrm{ab}$ & $73.33 c$ & $83.33 \mathrm{a}$ & $2.54 \mathrm{~d}$ & $10.06 \mathrm{a}$ & $6.30 \mathrm{a}$ \\
\hline $4.69 \mathrm{dS} \mathrm{m}^{-1}$ & $92 \mathrm{ab}$ & $71.33 \mathrm{c}$ & $81.67 \mathrm{a}$ & $2.82 \mathrm{~d}$ & $8.85 \mathrm{ab}$ & $5.83 a$ \\
\hline Mean & $93.20 \mathrm{a}$ & $77.87 \mathrm{~b}$ & & $2.54 b$ & $8.67 \mathrm{a}$ & \\
\hline \multicolumn{7}{|c|}{$2^{\text {nd }}$ season } \\
\hline $0.42 \mathrm{dS} \mathrm{m}^{-1}$ & $96.00 \mathrm{a}$ & $85.33 \mathrm{bc}$ & $90.67 \mathrm{a}$ & $2.36 \mathrm{~d}$ & $7.00 \mathrm{c}$ & $4.68 \mathrm{c}$ \\
\hline $2.34 \mathrm{dS} \mathrm{m}^{-1}$ & $94.67 \mathrm{ab}$ & $78.00 \mathrm{~cd}$ & $86.33 \mathrm{ab}$ & $2.36 \mathrm{~d}$ & $8.16 b$ & $5.26 b c$ \\
\hline $3.13 \mathrm{dS} \mathrm{m}^{-1}$ & $94.00 \mathrm{ab}$ & $78.00 \mathrm{~cd}$ & 86.00ab & $2.60 \mathrm{~d}$ & $8.55 b$ & $5.57 \mathrm{ab}$ \\
\hline $3.91 \mathrm{dS} \mathrm{m}^{-1}$ & $92.67 \mathrm{ab}$ & $72.67 \mathrm{de}$ & $82.67 b c$ & $2.56 \mathrm{~d}$ & $10.00 \mathrm{a}$ & $6.28 \mathrm{a}$ \\
\hline $4.69 \mathrm{dS} \mathrm{m}^{-1}$ & $90.67 \mathrm{ab}$ & $67.33 \mathrm{e}$ & $79.00 \mathrm{c}$ & $3.03 \mathrm{~d}$ & $9.17 \mathrm{ab}$ & $6.10 \mathrm{a}$ \\
\hline Mean & $93.60 \mathrm{a}$ & $76.27 b$ & & $2.58 \mathrm{~b}$ & $8.58 \mathrm{a}$ & \\
\hline
\end{tabular}

G.P.= Germination percentage (\%); M. G. T. = Mean germination Time and F. P. = Filter paper.

\section{3- Mean germination rate (M. G. R)}

Table (4) shows that, filter paper as a germination medium surpassed the other medium (sand) on the mean germination rate with significant differences between them of chia seeds in both seasons.

Concerning the effect of salinity concentrations in both seasons, it was interested to note that there was a negative relationship between mean germination rate values and salinity concentrations, hence, as the concentrations of salinity increased, the values of mean germination rate decreased to reach the lowest decreasing at the high salinity concentration (4.69 dS m $\mathrm{m}^{-1}$ ), with non-significant differences between them.

Therefore, in both seasons $\left(0.42 \mathrm{dS} \mathrm{m}^{-1}\right)$ soaked seeds scored the highest values of the mean germination rate of chia. Additionally, the combination treatment between filter paper and 0.42 $\mathrm{dS} \mathrm{m} \mathrm{m}^{-1}$ or $2.34 \mathrm{dS} \mathrm{m}^{-1}$ salinity concentration scored the highest values of mean germination rate in the first and the second seasons.

On the reverse, the lowest values of this parameter were resulted by the combination treatments of sand media and $3.91 \mathrm{dS} \mathrm{m}^{-1}$ in the two seasons.

\section{4- Germination index (G. I.)}

Data in Table (4) revealed that, using filter paper as a germination media exhibited to be the most effective one for producing the highest germination index of chia (Salvia hispanica $\mathrm{L}$.) seeds in $1^{\text {st }}$ and $2^{\text {nd }}$ seasons.

However, all tested concentration treatments of salinity decreased germination index of chia, especially the high salinity concentration $4.69 \mathrm{dS} \mathrm{m}^{-1}$ as compared to $0.42 \mathrm{dS} \mathrm{m}^{-1}$ (control) in the two seasons.

Moreover, all the combination treatments of salinity concentration and media succeeded in decreasing this parameter in the two seasons. In both seasons, the highest values of this parameter were recorded by the combination treatments of salinity concentration at $0.42 \mathrm{dS} \mathrm{m} \mathrm{m}^{-1}$ with filter paper followed in descending order by the combination treatments of $2.34 \mathrm{dS} \mathrm{m}^{-1}$ with filter paper media.

On the contrary, the lowest values of this parameter were gained by the combination treatments of salinity concentration at $4.69 \mathrm{dS} \mathrm{m} \mathrm{m}^{-1}$ with sand media in the two seasons. The remained treatments occupied an intermediate position between the above mentioned treatments. 
Table 4. Effect of germination media, saline water and their interaction treatments on a mean germination rate $\left(\right.$ day $\left.^{-1}\right)$ and the germination index (seed day ${ }^{-1}$ ) of chia (Salvia hispanica L.) seeds

\begin{tabular}{|c|c|c|c|c|c|c|}
\hline \multirow{3}{*}{ Salinity } & \multicolumn{3}{|c|}{ M. G. R. $\left(\right.$ day $\left.^{-1}\right)$} & \multicolumn{3}{|c|}{ G. I $\left(\right.$ seed day $\left.^{-1}\right)$} \\
\hline & \multicolumn{2}{|c|}{ Media } & \multirow{2}{*}{ Mean } & \multicolumn{2}{|c|}{ Media } & \multirow{2}{*}{ Mean } \\
\hline & F.P. & Sand & & F. P. & Sand & \\
\hline \multicolumn{7}{|c|}{$1^{\text {st }}$ season } \\
\hline $0.42 \mathrm{dS} \mathrm{m}^{-1}$ & $0.424 \mathrm{a}$ & $0.144 b c d$ & $0.284 a$ & $21.61 \mathrm{a}$ & $6.40 \mathrm{~d}$ & $14.01 \mathrm{a}$ \\
\hline $2.34 \mathrm{dS} \mathrm{m}^{-1}$ & $0.423 \mathrm{a}$ & $0.123 \mathrm{~cd}$ & $0.273 \mathrm{a}$ & $21.02 \mathrm{ab}$ & $4.83 \mathrm{e}$ & $12.92 b$ \\
\hline $3.13 \mathrm{dS} \mathrm{m}^{-1}$ & $0.390 \mathrm{abc}$ & $0.118 \mathrm{~d}$ & $0.254 \mathrm{a}$ & $20.14 a b c$ & $4.59 \mathrm{e}$ & $12.36 \mathrm{bc}$ \\
\hline $3.91 \mathrm{dS} \mathrm{m}^{-1}$ & $0.392 \mathrm{abc}$ & $0.101 d$ & $0.247 \mathrm{a}$ & $20.12 b c$ & $3.81 \mathrm{e}$ & $11.47 \mathrm{bc}$ \\
\hline $4.69 \mathrm{dS} \mathrm{m}^{-1}$ & $0.330 \mathrm{abcd}$ & $0.110 \mathrm{~d}$ & $0.220 \mathrm{a}$ & $18.90 \mathrm{c}$ & $4.18 \mathrm{e}$ & $11.54 \mathrm{c}$ \\
\hline Mean & $0.392 \mathrm{a}$ & $0.177 \mathrm{~b}$ & & $20.36 \mathrm{a}$ & $4.76 b$ & \\
\hline \multicolumn{7}{|c|}{$2^{\text {nd }}$ season } \\
\hline $0.42 \mathrm{dS} \mathrm{m}^{-1}$ & $0.423 a$ & $0.146 b c d$ & $0.283 a$ & $22.06 a$ & $6.39 \mathrm{e}$ & $14.23 \mathrm{a}$ \\
\hline $2.34 \mathrm{dS} \mathrm{m}^{-1}$ & $0.422 \mathrm{a}$ & $0.115 \mathrm{~cd}$ & $0.268 \mathrm{a}$ & $21.38 \mathrm{ab}$ & $5.06 f$ & $13.22 b$ \\
\hline $3.13 \mathrm{dS} \mathrm{m}^{-1}$ & $0.386 a b$ & $0.123 \mathrm{~cd}$ & $0.254 \mathrm{a}$ & $20.36 b c$ & $4.77 f g$ & $12.56 b c$ \\
\hline $3.91 \mathrm{dS} \mathrm{m}^{-1}$ & $0.396 \mathrm{ab}$ & $0.100 \mathrm{~d}$ & $0.248 \mathrm{a}$ & $19.96 \mathrm{c}$ & $3.80 \mathrm{~g}$ & $11.88 \mathrm{c}$ \\
\hline $4.69 \mathrm{dS} \mathrm{m}^{-1}$ & $0.355 \mathrm{abc}$ & $0.114 \mathrm{~cd}$ & $0.234 \mathrm{a}$ & $18.16 \mathrm{~d}$ & $3.80 \mathrm{~g}$ & $10.98 \mathrm{~d}$ \\
\hline Mean & $0.396 \mathrm{a}$ & $0.119 \mathrm{~b}$ & & $20.38 \mathrm{a}$ & $4.77 b$ & \\
\hline
\end{tabular}

M. G. R. = Mean germination rate; G. I. = Germination index and F. P. = Filter paper.

5- Coefficient of variation of germination time $(C$. $\mathrm{V}_{\mathrm{t}}$ )

Table (5) declares that, in the two seasons using filter paper as a germination medium resulted highly statistically increases of coefficient of variation of germination time as compared to sand media of germination time of chia seeds.

In this concern, all tested concentration treatments of salinity scored slightly decreases of this parameter with the exception of the high salinity concentration $4.69 \mathrm{dS} \mathrm{m}^{-1}$ with non-significant differences between them in both seasons. The highest values of coefficient of variation of germination time were recorded by the combination treatments of salinity concentration at $4.69 \mathrm{dS} \mathrm{m}^{-1}$ with filter paper followed in descending order by the combination treatments of $3.13 \mathrm{dS} \mathrm{m}^{-1}$ with filter paper media in the two seasons.

The third values in this respect, was scored by the combination treatments of salinity concentration at $0.42 \mathrm{dS} \mathrm{m}^{-1}$ (control) with filter paper. On the reverse, the lowest values of this parameter were gained by the combination treatments of salinity concentration at $4.69 \mathrm{dS} \mathrm{m}^{-1}$ with sand media in both seasons.

Table 5. Effect of germination media, saline water and their interaction treatments on coefficient of variation of germination time $(\%)$ and mean daily germination $\left(\right.$ day $\left.^{-1}\right)$ of chia (Salvia hispanica L.) seeds

\begin{tabular}{|c|c|c|c|c|c|c|}
\hline \multirow{3}{*}{ Salinity } & \multicolumn{3}{|c|}{ C. $V_{t}(\%)$} & \multicolumn{3}{|c|}{ M. D. G. $\left(\right.$ day $\left.^{-1}\right)$} \\
\hline & \multicolumn{2}{|c|}{ Media } & \multirow{2}{*}{ Mean } & \multicolumn{2}{|c|}{ Media } & \multirow{2}{*}{ Mean } \\
\hline & F.P. & Sand & & F.P. & Sand & \\
\hline \multicolumn{7}{|c|}{$1^{\text {st }}$ season } \\
\hline $0.42 \mathrm{dS} \mathrm{m}^{-1}$ & $42.17 \mathrm{ab}$ & $21.79 \mathrm{cde}$ & $32.25 \mathrm{a}$ & $1.91 \mathrm{ab}$ & $0.57 b$ & $1.24 \mathrm{a}$ \\
\hline $2.34 \mathrm{dS} \mathrm{m}^{-1}$ & $33.43 \mathrm{bcd}$ & $15.49 \mathrm{e}$ & $24.46 \mathrm{a}$ & 2.99ab & $0.50 \mathrm{~b}$ & $1.74 \mathrm{a}$ \\
\hline $3.13 \mathrm{dS} \mathrm{m}^{-1}$ & $44.92 \mathrm{ab}$ & 17.90de & $31.41 \mathrm{a}$ & $3.29 \mathrm{a}$ & $0.46 b$ & $1.87 \mathrm{a}$ \\
\hline $3.91 \mathrm{dS} \mathrm{m}^{-1}$ & $37.94 \mathrm{abc}$ & $17.88 \mathrm{de}$ & $27.91 \mathrm{a}$ & $2.21 \mathrm{ab}$ & $0.40 \mathrm{~b}$ & $1.31 \mathrm{a}$ \\
\hline $4.69 \mathrm{dS} \mathrm{m}^{-1}$ & $51.91 \mathrm{a}$ & $12.01 \mathrm{e}$ & $33.46 \mathrm{a}$ & $1.28 \mathrm{ab}$ & $0.56 b$ & $0.92 \mathrm{a}$ \\
\hline Mean & $42.78 \mathrm{a}$ & $17.01 \mathrm{~b}$ & & $2.34 \mathrm{a}$ & $0.50 \mathrm{~b}$ & \\
\hline \multicolumn{7}{|c|}{$2^{\text {nd }}$ season } \\
\hline $0.42 \mathrm{dS} \mathrm{m}^{-1}$ & $42.25 b$ & $23.63 \mathrm{~cd}$ & $32.94 a$ & $1.65 \mathrm{abc}$ & $0.58 \mathrm{bcd}$ & $1.12 \mathrm{a}$ \\
\hline $2.34 \mathrm{dS} \mathrm{m}^{-1}$ & $33.32 \mathrm{bc}$ & $22.65 \mathrm{~cd}$ & $27.98 \mathrm{a}$ & $2.55 \mathrm{a}$ & $0.49 \mathrm{~cd}$ & $1.52 \mathrm{a}$ \\
\hline $3.13 \mathrm{dS} \mathrm{m}^{-1}$ & $45.08 \mathrm{~b}$ & $18.74 d$ & $31.91 \mathrm{a}$ & $2.32 \mathrm{a}$ & $0.44 d$ & $1.38 \mathrm{a}$ \\
\hline $3.91 \mathrm{dS} \mathrm{m}^{-1}$ & $40.72 b$ & $17.95 \mathrm{~d}$ & $29.34 \mathrm{a}$ & $1.72 \mathrm{ab}$ & $0.40 \mathrm{~d}$ & $1.06 \mathrm{a}$ \\
\hline $4.69 \mathrm{dS} \mathrm{m}^{-1}$ & $60.59 \mathrm{a}$ & $13.68 \mathrm{~d}$ & $37.13 \mathrm{a}$ & $1.01 \mathrm{bcd}$ & $0.46 \mathrm{~d}$ & $0.74 \mathrm{a}$ \\
\hline Mean & $44.39 \mathrm{a}$ & $19.33 b$ & & $1.85 \mathrm{a}$ & $0.47 b$ & \\
\hline
\end{tabular}

C. $V_{t}=$ Coefficient of variation of germination time; M.D. G. = Mean daily germination and F. P. = Filter paper. 
6- Mean daily germination (M. D. G.)

Data in Table (5) demonstrated that in the two seasons, using filter paper as a germination media showed to be the most effective one for producing the highest mean daily germination as it were 2.34 and 1.85 of chia (Salvia hispanica L.) seeds in the first and the second seasons, respectively. All studied concentrations of salinity failed to induce a remarkable effect concerning this parameter in the two seasons. However, the highest mean daily germination was recorded by $3.13 \mathrm{dS} \mathrm{m} \mathrm{m}^{-1}$ salinity concentration in the first season only, while $2.34 \mathrm{dS}$ $\mathrm{m}^{-1}$ resulted the highest values of this parameter in the second season, with none significant differences between all salinity concentration of this parameter in both seasons. Moreover, the combination treatments between the medium concentration of salinity $\left(3.13 \mathrm{dS} \mathrm{m}^{-1}\right)$ with filter paper medium were the most effective for producing the highest mean daily germination of chia seeds in the two seasons. Additionally, in both seasons the lowest values of this parameter were recorded by the combination treatments of salinity concentration at $3.91 \mathrm{dS} \mathrm{m}^{-1}$ with sand medium.

\section{7- Peak value for germination (P. V.)}

Data in Table (6) demonstrated that, using filter paper as a germination medium resulted highly statistically increases of peak value for germination as compared with the other medium of chia (Salvia hispanica L.) seeds in both seasons.

Table 6. Effect of germination media, saline water and their interaction treatments on peak value $\left(\right.$ day $\left.^{-1}\right)$ for germination and germination value $\left(\%^{2} \mathrm{day}^{-2}\right)$ of chia (Salvia hispanica L.) seeds

\begin{tabular}{|c|c|c|c|c|c|c|}
\hline \multirow{3}{*}{ Salinity } & \multicolumn{3}{|c|}{ P. V. $\left(\right.$ day $\left.^{-1}\right)$} & \multicolumn{3}{|c|}{ G. V. $\left(\%^{2}\right.$ day $\left.^{-2}\right)$} \\
\hline & \multicolumn{2}{|c|}{ Media } & \multirow{2}{*}{ Mean } & \multicolumn{2}{|c|}{ Media } & \multirow{2}{*}{ Mean } \\
\hline & F.P. & Sand & & F.P. & Sand & \\
\hline \multicolumn{7}{|c|}{$1^{\text {st }}$ season } \\
\hline $0.42 \mathrm{dS} \mathrm{m}^{-1}$ & 7.05ab & $3.63 b c$ & $5.34 \mathrm{a}$ & $14.93 a$ & $2.09 a$ & $8.55 \mathrm{a}$ \\
\hline $2.34 \mathrm{dS} \mathrm{m}^{-1}$ & $8.88 \mathrm{a}$ & $3.30 \mathrm{bc}$ & $6.09 \mathrm{a}$ & $29.41 \mathrm{a}$ & $1.65 \mathrm{a}$ & $15.53 \mathrm{a}$ \\
\hline $3.13 \mathrm{dS} \mathrm{m}^{-1}$ & $8.75 a$ & $2.98 \mathrm{c}$ & $5.86 \mathrm{a}$ & $42.02 \mathrm{a}$ & $1.47 \mathrm{a}$ & $21.74 \mathrm{a}$ \\
\hline $3.91 \mathrm{dS} \mathrm{m}^{-1}$ & $7.65 a$ & $2.82 \mathrm{c}$ & $5.24 \mathrm{a}$ & $17.95 \mathrm{a}$ & $1.14 \mathrm{a}$ & $9.55 \mathrm{a}$ \\
\hline $4.69 \mathrm{dS} \mathrm{m}^{-1}$ & $5.75 \mathrm{abc}$ & $3.26 \mathrm{bc}$ & $4.50 \mathrm{a}$ & $7.38 \mathrm{a}$ & $1.99 \mathrm{a}$ & $4.68 \mathrm{a}$ \\
\hline Mean & $7.61 \mathrm{a}$ & $3.20 \mathrm{~b}$ & & $22.34 \mathrm{a}$ & $1.67 \mathrm{~b}$ & \\
\hline \multicolumn{7}{|c|}{$2^{\text {nd }}$ season } \\
\hline $0.42 \mathrm{dS} \mathrm{m}^{-1}$ & $6.67 \mathrm{ab}$ & $3.66 \mathrm{~cd}$ & $5.17 \mathrm{ab}$ & $11.43 \mathrm{ab}$ & $2.12 b$ & $6.78 \mathrm{a}$ \\
\hline $2.34 \mathrm{dS} \mathrm{m}^{-1}$ & $8.40 \mathrm{a}$ & $3.21 \mathrm{~cd}$ & $5.81 \mathrm{a}$ & $21.60 \mathrm{ab}$ & $1.65 b$ & $11.62 \mathrm{a}$ \\
\hline $3.13 \mathrm{dS} \mathrm{m}^{-1}$ & $7.57 \mathrm{a}$ & $3.02 \mathrm{~cd}$ & $5.30 \mathrm{ab}$ & $22.12 \mathrm{a}$ & $1.37 \mathrm{~b}$ & $11.74 \mathrm{a}$ \\
\hline $3.91 \mathrm{dS} \mathrm{m}^{-1}$ & $6.72 \mathrm{ab}$ & $2.80 \mathrm{~d}$ & $4.58 \mathrm{ab}$ & $11.89 \mathrm{ab}$ & $1.12 \mathrm{~b}$ & $6.51 \mathrm{a}$ \\
\hline $4.69 \mathrm{dS} \mathrm{m}^{-1}$ & $5.04 \mathrm{bc}$ & $2.89 \mathrm{~cd}$ & $3.97 \mathrm{~b}$ & $5.08 \mathrm{~b}$ & $1.45 \mathrm{~b}$ & $3.26 \mathrm{a}$ \\
\hline Mean & $6.88 \mathrm{a}$ & $3.12 b$ & & $14.42 \mathrm{a}$ & $1.54 \mathrm{~b}$ & \\
\hline
\end{tabular}

P. V. = peak value for germination; G. V. = germination value and F. P. = Filter paper.

On the other hand, the concentration of salinity at $2.34 \mathrm{dS} \mathrm{m} \mathrm{m}^{-1}$ gave the highest values of this parameter with non-significant differences between them in the first season only. In this concern, the combination treatment between filter paper and 2.34 $\mathrm{dS} \mathrm{m}^{-1}$ salinity concentration scored the highest values of peak value for germination of chia seed followed in descendingly by the combination treatment between filter paper and $3.13 \mathrm{dS} \mathrm{m} \mathrm{m}^{-1}$ salinity concentration with non-significant differences between them in $1^{\text {st }}$ and $2^{\text {nd }}$ seasons.

On the opposite, the lowest values of this parameter were gained by the combination treatments of sand media and $3.91 \mathrm{dS} \mathrm{m}^{-1}$ salinity concentration in the two seasons.

8- Germination value (G. V.)

Data in Table (6) illustrated that, using filter paper as a germination medium resulted in highly significant increases of germination value as compared with the other medium of chia (Salvia hispanica L.) seeds in both seasons.

On the other hand, the concentration of salinity at $3.13 \mathrm{dS} \mathrm{m}^{-1}$ gave the highest values of this parameter with non-significant differences between them in the two seasons. Moreover, the combination treatment between filter paper and $3.13 \mathrm{dS} \mathrm{m} \mathrm{m}^{-1}$ salinity concentration was scored the highest values of germination of chia seed followed descendingly by the combination treatment between filter paper and $2.34 \mathrm{dS} \mathrm{m}^{-1}$ salinity concentration with nonsignificant differences between them in the first season only.

On the reverse, the lowest values of this parameter were gained by the combination treatments of sand media and $3.91 \mathrm{dS} \mathrm{m}^{-1}$ salinity concentration in the two seasons. The remained treatments occupied an intermediate position between the above mentioned treatments. 


\section{9- Time to $50 \%$ and $90 \%$ germination $\left(\mathrm{T}_{50}\right.$ and T90)}

Data in Table (7) declared that, using the sand medium as a germination media showed to be the most effective one for producing the highest $\mathrm{T}_{50}$ and $\mathrm{T}_{90}$ of chia (Salvia hispanica L.) seeds in both seasons. As for the effect of salinity of germination percentage data in the same Table illustrated that, all tested concentrations of salinity increased $\mathrm{T}_{50}$ and $\mathrm{T}_{90}$ of chia seeds, particularly the combination of $3.91 \mathrm{dS}$ $\mathrm{m}^{-1}$, followed in descending order by $4.69 \mathrm{dS} \mathrm{\textrm {m } ^ { - 1 }}$ treated chia seeds without significant differences between them in the two seasons.

Concerning the interaction effect between germination media and salinity, it was found that all resulted combination between germination media and salinity increased $\mathrm{T}_{50}$ and $\mathrm{T}_{90}$ of chia seeds in both seasons. The highest values of these parameters were gained by the combination of $3.91 \mathrm{dS} \mathrm{m}^{-1}$, with sand medium, followed in descending order by the combination treatment of $4.91 \mathrm{dS} \mathrm{m}^{-1}$ with sand medium in $1^{\text {st }}$ and $2^{\text {nd }}$ seasons.

The third values in this respect, was scored by the combination treatments of salinity concentration at $2.34 \mathrm{dS} \mathrm{m}^{-1}$ with sand medium in most cases. On the reverse, the lowest values of these parameters were scored by the combination of low salinity concentration $\left(0.42 \mathrm{dS} \mathrm{m}^{-1}\right.$ as control), with the filter paper medium in both seasons. The remained treatments occupied an intermediate position between the above mentioned treatments.

Table 7. Effect of germination media, saline water and their interaction treatments on time to $50 \%$ germination (day) and time to $90 \%$ germination (day) of chia (Salvia hispanica L.) seeds

\begin{tabular}{|c|c|c|c|c|c|c|}
\hline \multirow{3}{*}{ Salinity } & \multicolumn{3}{|c|}{$\mathbf{T}_{50}$ (day) } & \multicolumn{3}{|c|}{ T90 (day) } \\
\hline & \multicolumn{2}{|c|}{ Media } & \multirow{2}{*}{ Mean } & \multicolumn{2}{|c|}{ Media } & \multirow{2}{*}{ Mean } \\
\hline & F.P. & Sand & & F. P. & Sand & \\
\hline \multicolumn{7}{|c|}{$1^{\text {st }}$ season } \\
\hline $0.42 \mathrm{dS} \mathrm{m}^{-1}$ & $1.61 d$ & $6.01 \mathrm{c}$ & $3.81 \mathrm{~b}$ & $2.68 c$ & $8.79 b$ & $5.73 b$ \\
\hline $2.34 \mathrm{dS} \mathrm{m}^{-1}$ & $1.67 \mathrm{~d}$ & $8.26 a b$ & $4.96 \mathrm{a}$ & $2.80 \mathrm{c}$ & $10.20 \mathrm{~b}$ & 6.50ab \\
\hline $3.13 \mathrm{dS} \mathrm{m}^{-1}$ & $1.75 \mathrm{~d}$ & $7.44 \mathrm{bc}$ & $4.59 \mathrm{ab}$ & $3.53 c$ & $9.81 b$ & $6.67 \mathrm{ab}$ \\
\hline $3.91 \mathrm{dS} \mathrm{m}^{-1}$ & $1.78 \mathrm{~d}$ & $9.74 \mathrm{a}$ & $5.63 \mathrm{a}$ & $2.85 \mathrm{c}$ & $12.39 \mathrm{a}$ & $7.62 \mathrm{a}$ \\
\hline $4.69 \mathrm{dS} \mathrm{m}^{-1}$ & $1.84 \mathrm{~d}$ & $8.21 \mathrm{ab}$ & $5.03 \mathrm{a}$ & $4.45 c$ & $9.99 \mathrm{~b}$ & $7.22 \mathrm{a}$ \\
\hline Mean & $1.73 b$ & $7.88 \mathrm{a}$ & & $3.26 \mathrm{~b}$ & $10.23 a$ & \\
\hline \multicolumn{7}{|c|}{$2^{\text {nd }}$ season } \\
\hline $0.42 \mathrm{dS} \mathrm{m}^{-1}$ & $1.61 d$ & $6.05 \mathrm{c}$ & $3.83 \mathrm{c}$ & $2.79 \mathrm{~d}$ & $9.07 b$ & $5.93 c$ \\
\hline $2.34 \mathrm{dS} \mathrm{m}^{-1}$ & $1.66 \mathrm{~d}$ & $7.37 \mathrm{~b}$ & $4.51 b c$ & $2.81 \mathrm{~d}$ & $10.28 \mathrm{~b}$ & $6.55 b c$ \\
\hline $3.13 \mathrm{dS} \mathrm{m}^{-1}$ & $1.73 \mathrm{~d}$ & $7.68 b$ & $4.71 b$ & $3.32 \mathrm{~cd}$ & $10.31 \mathrm{~b}$ & $6.82 \mathrm{abc}$ \\
\hline $3.91 \mathrm{dS} \mathrm{m}^{-1}$ & $1.76 \mathrm{~d}$ & $9.35 \mathrm{a}$ & $5.56 \mathrm{a}$ & $3.12 \mathrm{~d}$ & $12.33 \mathrm{a}$ & $7.73 \mathrm{ab}$ \\
\hline $4.69 \mathrm{dS} \mathrm{m}^{-1}$ & $1.90 \mathrm{~d}$ & $8.36 \mathrm{ab}$ & $5.13 \mathrm{ab}$ & $5.20 \mathrm{c}$ & $10.86 \mathrm{ab}$ & $8.03 \mathrm{a}$ \\
\hline Mean & $1.73 b$ & $7.76 \mathrm{a}$ & & $3.45 b$ & $10.57 \mathrm{a}$ & \\
\hline
\end{tabular}

$\mathrm{T}_{50}=$ Time to $50 \%$ germination; $\mathrm{T}_{90}=$ Time to $90 \%$ germination and $\mathrm{F}$. $\mathrm{P} .=$ Filter paper.

\section{Discussion}

The results of using filter paper and sand as a medium of germination experiment are in agreement with those obtained by Trivedia and Joshi, (2014) in which filter paper increased all studied traits included germination percentage recorded $60 \%$ and $35 \%$ as final percentages in filter paper and sand, respectively. The same trend recorded in germination rate, germination index and mean daily germination compared to sand; Kumar and Sharma, (2012) studied the germination of three plants Stevia rebaudiana, Tagets minuta and Salvia sclarea under light, temperature and two growing media (sand and filter paper).

The results of Stevia rebaudiana recorded 58.77 $\%$ and $54.7 \%$ germination percentages in sand and paper media, Tagets minuta scored $54.3 \%$ and $22.75 \%$ in two media, respectively. While, Salvia sclarea in paper recorded $89.3 \%$ and in sand the percentage recorded was 76.0\%; Gautam and Rahul, (2013) on Plumbago zeylanica L., showed that, sand $(0 \%$ soil $+100 \%$ sand $)$ gave the best germination percentage compared with $(50 \%$ soil + $50 \%$ sand) and $(25 \%$ soil $+75 \%$ sand $)$. Also Dharmveer, et al., (2016) on Angelica glauca Edgew, the results showed that the sand, soil, cocopeat and vermicompost have significant positive effects on seed germination and seedling development; Pulatkan, et al., (2017) on Spartium junceum $\mathrm{L}$, found that the germination of seeds has been scored: peat 34\%, peat + soil (7: 3) $35.33 \%$ and peat + sand (7: 3) $42.67 \%$. In addition, Wang, et al., (2017) on Anabasis aphylla. showed that sand burial significantly affected seed germination, seedling emergence and survival. On the other hand, Gairola, et al., (2011) on Jatropha Curcas Linn, shown that, the highest germination percentage was recorded by 
vermiculite scored 85\%, sand recorded $82.5 \%$ whereas filter paper scored $55 \%$.

The obtained results of salinity are in agreement with those obtained by Gorai, et al., (2011) on Salvia aegyptiaca, Dadach and Mehdadi, (2016) on Thymus fontanesii Boiss, Camlica and Yaldiz, (2017) on Ocimum basilicum, Dadach, et al., (2018) on Marrubium vulgare, Sideritis incana and Stachys ocymastrum and Paiva, et al., (2018) on Salvia hispanica L. illustrated that, Salinity levels above 4.5 $\mathrm{dS} \mathrm{m}{ }^{-1}$ together with temperatures of 30 or $20-30^{\circ} \mathrm{C}$ negatively affected the germination, vigor, growth and biochemical components of Salvia hispanica L. seedlings.

In the earlier studies in the literature, harmful effects of high salinity effects on crops are multi directional and affect plants in several ways as drought stress, ion toxicity, nutritional disorders, oxidative stress, alteration of metabolic processes, membrane disorganization and reduction of cell division and expansion (Hasegawa, et al., 2000 and Sidari, et al., 2008). Therefore, it was reported that plant growth, development and survival were reduced (Muscolo, et al., 2013 and Schleiff and Muscolo, 2011). Salinity made seedlings to grow slowly or less mobilization of food which is reserved, deferring the cell division, growing and injuring hypocotyls (Rahman, et al., 2008).

Under normal conditions, a large portion of the energy is extracted from the reserves and consumed during the transport of ions and the synthesis of compatible solutes for development (Flowers and Colmer, 2008). However, when seeds are subjected to salt stress conditions, part of the energy from the reserves is consumed during the transport of the $\mathrm{Na}^{+}$ ions, leading to serious damage to seedling development and eventually preventing their development, this fact was observed also in the present study.

Salt stress decreased both the rate and percentage of germination of $S$. aegyptiaca. This result corroborates several other studies, revealing that halophytes, as glycophytes, are sensitive to salt during the germination stage (Ungar, 1995; Katembe, et al., 1998; Khan, et al., 2002 and Gorai and Neffati, 2007).

Conclusively, the present study strongly admits the use of filter paper as germination media and 0.42 $\mathrm{dS} \mathrm{m}^{-1}$ salinity concentration to get the best germination percentage of chia (Salvia hispanica L.) seeds in the two seasons.

\section{References}

Agbo, C. U. and C. M. Omaliko (2006). Initiation and growth of shoots of Gongronema latifolia Benth stem cuttings in different rooting media. African Journal of Biotechnology, 5 (5): 425-428.

Ali, N. M.; Yeap, S. K.; Ho, W. Y.; Beh, B. K.; Tan, S. W. and S. G. Tan (2012). The promising future of chia Salvia hispanica L., Journal of Biomedicine and Biotechnology, 2012: 1-9.

Al-Khateeb, S. A. (2006). Effect of salinity and temperature on germination, growth and ion relations of Panicum turgidum Forssk. Bioresource Technology, 97: 292-298.

A. O. S. A. (1983). Seed Vigor Testing Handbook. Contribution No.32 to handbook on seed testing. Association of Official Seed Analysis.

Ayerza, R. and W. Coates (2000). Dietary levels of chia influence on yolk cholesterol, lipid content and fatty acid composition, for two strains of hens. Poultry Science, 78: 724-739.

Ayerza. R. and W. Coates (2005) Ground chia seed and chia oil effects on plasma lipids and fatty acids in the rat. Nutrition Research, 25 (11): 9951003.

Bresson, J. L.; Flynn, A.; Heinonen, M.; Hulshof, K.; Korhonen, H.; Lagiou, P.; Løvik, M.; Marchelli, R.; Martin, A.; Moseley, B.; Przyrembel, H.; Salminen, S.; Strain, J. J.; Strobel, S.; Tetens, I.; Berg, H.; Loveren, H. and H. Verhagen (2009). Opinion on the safety of chia seeds (Salvia hispanica L.) and ground whole chia seeds as a food ingredient. The European Food Safety Authority Journal, 996: 126.

Bueno, M.; Sapio, O.; Barolo, M.; Busilacchi, H.; Quiroga, M. and C. Severin (2010). Quality tests of Salvia hispanica L. (Lamiaceae) fruits marketed in the city of Rosario (Santa Fe province, Argentina)," Boletin Latinoamericano y del Caribe de Plantas Medicinales y Arom' aticas, 9 (3): 221-227.

Cahill, J. P. and M. C. Provance (2002). Genetics of qualitative traits in domesticated chia (Salvia hispanica L.). Journal of Heredity, 93 (1): 52-55.

Camlica, M. and G. Yaldiz (2017). Effect of salt stress on seed germination, shoot and root length in basil (Ocimum basilicum). International Journal of Secondary Metabolite, 4 (3): 69-76.

Carbonell, M. V; Martinez, E.; Florez, M.; Maqueda, R.; Lopez-Pintor, A. and J. M. Amaya (2008). Magnetic field treatments improve germination and seedling growth in Festuca arundinacea Schreb and Loliumperenne L. Seed Science and Technology, 36: 31-37.

Coolbear, P.; Francis, A. and D. Grierson (1984). The effect of low temperature pre-sowing under the germination performance and membrane integrity of artificially aged tomato seeds. Journal of Experimental Botany, 35: 1609-1617.

Czabator, F. J. (1962). Germination value: An index combining speed and completeness of pine seed germination. Forest Science, 8: 386 - 395.

Dadach, M. and Z. Mehdadi (2016). Testing the effect of temperature and salinity on germination behavior of Thymus Fontanesii Boiss. \& Reut. Advances in Natural and Applied Sciences, 10 (4): 372-378. 
Dadach, M.; Mehdadi, Z. and A. Adjouj (2018). Evaluation of the tolerance to temperature and salinity on seed germination of three Lamiacea from Algerian scrubland. Advanced Research in Life Sciences, 2 (1): 11-15.

Dharmveer; Sood, M.; Aziem, S.; Iqbal, K.; Hussain, A. and S. Mahato (2016). Effect of different growing media on seed germination and growth parameters of Angelica glauca edgew. Indian Forester, 142 (11): 1093-1099.

Duncan, D. B. (1955). Multiple Range and Multiple F-Test. Biometrics, 11: 1-42.

Ellis, R. H. and E. H. Roberts (1981). The quantification of ageing and survival in orthodox seeds. Seed Science and Technology, 9: 373-409.

Farooq, M.; Basra, S. M. A.; Afzal, I. and Abdul Khaliq (2005). Optimization of hydropriming techniques for rice seed invigoration. Seed Science and Technology, 34 (2): 507-512.

Flowers, T. J. and T. D. Colmer (2008). Salinity tolerance in halophytes. New Phytologist, 179 (4): 945-963.

Flowers, T. J. and A. R. Yeo (1995). Breeding for salinity resistance in crop plant: where next?. Australian Journal of Plant Physiology, 22: 875884.

Gairola, K. C.; Nautiyal; A. R. and A. K. Dwivedi (2011). Effect of temperatures and germination media on seed germination of Jatropha Curcas Linn. Advances in Bioresearch, 2 (2): 66-71.

Gautam, A. and J. Rahul (2013). Seed germination and growth of chitrak (Plumbago zeylanica L.). International Journal of Botany and Research, 3 (4): 29-38.

Gorai, M. and M. Neffati (2007). Germination responses of Reaumuria vermiculata to salinity and temperature. Annals of Applied Biology, 151: 53-59.

Gorai, M.; Gasmi, H. and M. Neffati (2011). Factors influencing seed germination of medicinal plant Salvia aegyptiaca L. (Lamiaceae). Saudi Journal of Biological Sciences, 18: 255-260.

Hasegawa, P. M.; Bressan, R. A.; Zhu, J. K. and H. J. Bohnert (2000). Plant cellular and molecular responses to high salinity. Annual Review of Plant Physiology and Plant Molecular Biology, 51: 463-499.

Heidari, M. (2012). Effects of salinity stress on growth, chlorophyll content and osmotic components of two basil (Ocimum basilicum L.) genotypes. African Journal of Biotechnology, 11 (2): 379-384.

International Seed Testing Association (I. S. T. A.), (1999). International Rules For Seed Testing. Seed Science and Technology, 21: 288 pp.

International Seed Testing Association (I. S. T. A.), (2007). International Rules for Seed Testing. Bassersdorf, Switzerland ISTA News Bulletin, 133: 1-65.
International Seed Testing Association (I. S. T. A.), (2013). International Rules for Seed Testing. International Seed Testing Association. Switzerland, NW: Bassersdorf. Iowa State Univ. Press. Ames Iowa, USA, 503 pp.

Ixtaina, V. Y.; Nolasco, S. M. and M. C. Tomas (2008). Physical properties of chia (Salvia hispanica L.) seeds. Industrial Crops and Products, 28 (3): 286-293.

Katembe, W. J.; Ungar, I. A. and J. Mitchell (1998). Effect of salinity on germination and seedling growth of two Atriplex species (Chenopodiaceae). Annals of Botany, 82: 167175

Khan, M. A.; Gul, B. and D. J. Weber (2002). Seed germination in relation to salinity and temperature in Sarcobatus vermiculatus. Biologia Plantarum, 45: 133-135.

Kumar, R. and S. Sharma (2012). Effect of light and temperature on seed germination of important medicinal and aromatic plants in north western Himalayas. International Journal of Medicinal and Aromatic Plants, 2 (3): 468-475.

Munnas, R. (1993). Physiological processes limiting plant growth in saline soils: some dogmas and hypotheses. Plant, Cell \& Environment, 16 (1): 15-24.

Muscolo, A., Panuccio, M. R. and A. Heshel (2013). Ecophysiology of Pennisetum clandestinum: a valuable salt tolerant grass. Environmental and Experimental Botany, 92: 5563.

Ndor, E; Dauda, N. S. and H. B. Chammang (2012). Effect of germination media and seed size on germination and seedling vigour of fluted pumpkin (Telferia occidentalis) Hook. F. International Journal of Agricultural Sciences, 2 (3): 113-115.

Paiva, E. P.; Torres, S. B.; Alves, T. R. C., Silva Sá, F. V.; Leite, M. S. and J. L. D. Dombroski (2018). Germination and biochemical components of Salvia hispanica L. seeds at different salinity levels and temperatures. Acta Scientiarum, Agronomy, 40: 1-7.

Paiva, E. P.; Torres, S. B.; Silva Sá, F. V.; Nogueira, N. W.; Freitas, R. M. O. and M. S. Leite (2016). Light regime and temperature on seed germination in Salvia hispanica L. Acta Scientiarum, 38 (4): 513-519.

Peiretti, P. G. and F. Gai (2009). Fatty acid and nutritive quality of chia (Salvia hispanica L.) seeds and plant during growth. Animal Feed Science and Technology, 148 (2-4): 267-275.

Peiretti, P. G. and G. Meineri (2008). Effects on growth performance, carcass characteristics, and the fat and meat fatty acid profile of rabbits fed diets with chia (Salvia hispanica L.) seed supplements. Meat Science, 80 (4): 1116-1121.

Pulatkan, M.; Yildirim, N.; and I. Turna (2017). Effects of different medium on seed germination 
of Spartium junceum L. with medicinal and aromatic importance. International Journal of Secondary Metabolite, 4 (3): 376-383.

Rahman, M.; Soomro, U.; Zahoor-Ul-Hag, M. and S. H. Gul (2008). Effects of $\mathrm{NaCl}$ salinity on wheat (Triticum aestivum L.) cultivars. World Journal of Agricultural Sciences, 4 (3): 398-403.

Rainwater, F. H. and L. L. Thatcher (1960). Methods for collection and analysis of water samples, U.S. Geol. Surv. Water Supply Papers, 1454.

Ranal, M. A. and D. G. Santana (2006). How and why to measure the germination process?. Revista Brasileira de Botanica, 29 (1): 1-11.

Reyes-Caudillo, E.; Tecante, A. and M. A. Valdivia-Lopez (2008). Dietary fibre content and antioxidant activity of phenolic compounds present in Mexican chia (Salvia hispanica L.) seeds. Food Chemistry, 107 (2): 656-663.

Schleiff, U. and A. Muscolo (2011). Fresh look at plant salt tolerance as affected by dynamics at the soil/root-interface using Leek and Rape as model crops. The European Journal of Plant Science and Biotechnology, 5: 27-32.

Sidari, M.; Santonoceto, C.; Anastasi, U.; Preiti, G. and A. Muscolo (2008). Variations in four genotypes of lentil under $\mathrm{NaCl}$ salinity stress.
American Journal of Agriculture and Biological Science, 3: 410-416.

Snedecor, G. W. and W. G. Cochran (1989). Statistical methods. $7^{\text {th }}$ Ed. Iowa State Univ. Press. Ames Iowa, USA.

Sosa, L.; Llanes, A.; Reinoso, H.; Reginato, M. and V. Luna (2005). Osmotic and specifici ion effect on the germination of Prosopis strombu lifera. Annals of Botany, 96: 261-267.

Tlig, T. ; Gorai, M. and M. Neffati (2008). Germination responses of Diplotaxis harra to temperature and salinity. Flora, 203: 421-428.

Trivedia, D. R. and A. G. Joshi (2014). Studies on seed germination of Stereospermum suaveolens with respect to different parameters. Environmental and Experimental Biology, 12: 33-37.

Ungar, I. A. (1995). Seed germination and seedbank ecology of halophytes. In: Kigel, J., Galili, G. (Eds.), Seed Development and Germination. Marcel Dekker, New York, pp. 599-627.

Wang, T.; Chu, G.; Jiang, P.; Niu, P. and M. Wang (2017). Effects of sand burial and seed size on seed germination, seedling emergence and seedling biomass of Anabasis aphylla. Pakistan Journal of Botany, 49 (2): 391-396.

$$
\begin{aligned}
& \text { تأثير بيئة النمو والماء المالح على إنبات بذور الثيا (Salvia hispanica L) }
\end{aligned}
$$

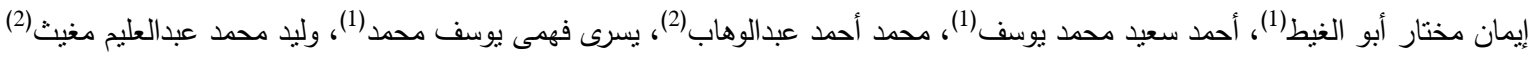

$$
\begin{aligned}
& \text { (1) قسم البساتين - كلية الزراعة بمشتهر - جامعة بنها } \\
& \text { (2) قسم النباتات الطبية والعطرية - مركز بحوث الصحراء }
\end{aligned}
$$

أجريت هذه الدراسة فى معمل مركز بحوث الصحراء فى موسمين متتابعين 2017/2016 و 2018/2017. هدفت الدراسة إلى دراسة

تحمل بذور الثيا المنبتة على ورق ترشيح أو تربة رملية للرى بالماء المالح. تم رى البذور كل يومين بنسبة 100 \% من السعة الحقلية من بداية زراعة البذور لنهاية التجربة (10-17 يوم) بإستخدام ماء الصنبور (2S m dS (0.42) أو ماء مالح أُعد بإضافة كلوريد الصوديوم إلى ماء الصنبور للوصول إلى أربع مستويات ملوحة (2.34, 3.13, 3.91 and 4.69 dS m²). أظهرت النتائج أن إستخدام ورق الترشيح كان الأفضل فى الحد من الأثار الغير مرغوبة للملوحة مقارنة بالرمل على معظم الصفات المدروسة. إرتفاع تركيز الملوحة إلى (4S m² d.69) قلل معظم صفات الإنبات (نسبة الإنبات، مؤشر الإنبات ومتوسط معدل الإنبات لبذور

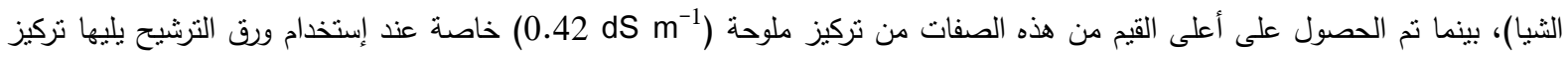
(2.34 dS m²) معدل تباين وقت الإنبات سجلت للمعاملة بأعلى تركيز ملوحة (4S m² dS (4.69) مع بيئة ورق الترشيح فى الموسمين، وعلى نحو آخر أعطت بيئة

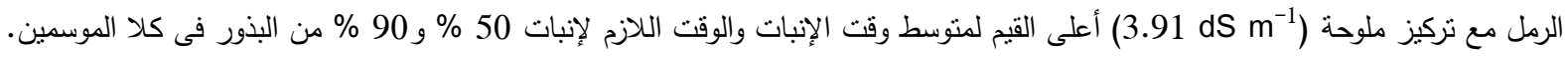
ونستخلص من النتائج أن إستخدام ورق الترشيح كبيئة إنبات مع أقل تركيز ملوحة (0.42 dS mن أعطى أفضل صفات إنبات، بالإضافة إلى إلى

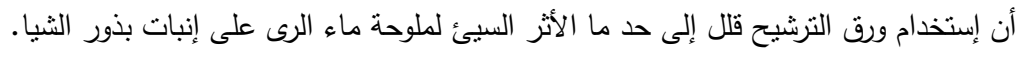

